\title{
The Social Interaction Of Students With Disabilities In Learning In Higher Education
} \author{
Ismail \\ Special Education Department \\ Universitas Lambung Mangkurat \\ Banjarmasin, Indonesia \\ rohmah.mursita@ulm.ac.id
}

Rohmah Ageng Mursita, Fathimatuzzahra, Eviani Damastuti, Mirnawati, Dewi Ekasari Kusumastuti, Murniyanti

\begin{abstract}
Social interaction is a relationship between two people or more that happens because of connected communication and socialization. In this study, social interaction is defined as the interactions between students with disabilities and regular students in a class, the social interaction among students with disabilities, and the social interaction between students with disabilities and volunteers. The social interactions by the students with disabilities in class appear in various patterns because of the different conditions of each student, communication methods, language perceptions, peers acceptance in class, volunteers and the students with disabilities themselves. This research is conducted to know the pattern of students with disabilities social interaction in learning session in the classroom. The research method used is a qualitative research with a case study approach. The data were collected through observation, interview, and documentation. The research subjects were students with disabilities, regular students, and volunteers. The result revealed that there are two patterns of social interaction in a class learning session. The first is the positive social interaction, formed by cooperations, understanding in communication, and acceptances from two sides. The other is the negative social interaction, the one with difficulties because some factors such as communication barrier, introvert personalities of students with disabilities, and the fears to start a communication.
\end{abstract}

Keywords—social interaction; students with disabilities; higher education; learning session.

\section{INTRODUCTION}

Indonesia has started implementing inclusive education starting from kindergarten to high school level. As of today, a new paradigm has been developed that inclusive education begins to be applied in universities. This is supported by the presence of Law number 8 of 2016 and PERMENRISTEKDIKTI number 46 of 2017. Inclusive education is believed by experts in education to be the most effective educational paradigm to actualize education for all. As a country that has ratified and agreed on the international agreement, Indonesia must implement it primarily to accommodate education for students/students with special needs.

The implementation of the international agreements is carried out through the Convention on the Rights of Persons with Disability which was passed by Law No. 19 of 2011. It also contains articles relating to inclusive in higher education, which states that people with disabilities must be accepted at all levels of education. Article 24 of the convention explains that students and students with disabilities must be facilitated with educational facilities and infrastructure, as well as improving skills for teachers and lecturers so that they are able to provide quality education for people with disabilities.

Persons with disabilities are entitled to access to education from an early age to higher education. The Government, through the Minister of Research and Higher Education Regulation Number 46 of 2017, issues regulations on special education, special service education and/or special service learning in universities. In the regulation, in Article 1, it is explained that special education is an educational service for students with needs in higher education, and in Article 2 explained the implementation of special education aims to: (a) expand access to education for students with special needs, (b) improve the quality of education services for students with special needs, appreciate diversity and equality for students with special needs.

The Minister of Technology Research and Higher Education, stated that higher education provides the widest access for persons with disabilities, and they have the same rights in education. The government is also obliged to facilitate all sectors, especially higher education. Even so, it is admitted that not many universities are friendly to people with disabilities because the number of people with disabilities are few yet there should still be access to support them. With the existence of several regulations as a basis such as Law Number 8 of 2016 and PERMENRISTEK DIKTI Number 46 of 2017, it is explained that people with disabilities are entitled to access higher education, and universities are also required to form a disability service unit. With some basic considerations as stated above, Lambung Mangkurat University has begun to accept students with disabilities in 2017.

The success of inclusive education in higher education is inseparable from how to build an inclusive class. One of the keys is by building a positive pattern of interaction between students with disabilities and students with disabilities, students with disabilities with non-disabled students, and students with disabilities with volunteers. 
According to [1], social interaction is the relationship between one individual with other individuals. Individual can influence another individual or vice versa, so there is a reciprocal relationship. Social interaction is an individual way to maintain the individual's social behavior so that individuals can still behave socially with other individuals. Social interaction can also increase the number or quantity and quality of individual social behavior so that individuals are more mature in social behavior with others in social situations [2]. According to [3], social interaction is the key to all social life because without social interaction there can be no life together.

Reference [3] argues that forms of social interaction are (1) cooperation, which means a joint effort between individuals or groups to achieve a goal, (2) accommodation, as a process in which individuals conflict with each other, then hold each other adjustment to overcome tensions. (3) Competition is defined as a process in which individuals or groups compete for profit through the field of life by attracting attention or sharpening pre-existing prejudices, without using violence or threats. Furthermore, (4) conflict is a social process in which individuals or groups try to fulfill goals by challenging opponents with threats or violence. According to the experts' explanation above, it can be concluded that the ability of social interaction is the ability of individuals to relate to and cooperate with other individuals and groups that individual behavior can influence, change, or improve the behavior of other individuals or vice versa so that there is a reciprocal relationship.

Positive social interaction will have a good impact on each individual who engages in social interaction. In social interaction, good communication, good characters and mutual respect between communicators and communicants in social interaction are needed. We need to know that people with disabilities experience difficulties and some obstacles in social interaction, due to both internal factors and external factors.

The purpose of this study is to determine the patterns of social interaction of students with disabilities with nondisabilities, students with disabilities and students with disabilities, and students with disabilities with volunteers. Limitations on the subject of this research were students with disabilities at Lambung Mangkurat University in special education programs. There were 7 disability students in the education study program.

\section{METHOD}

The research method used in this study is a descriptive method with a qualitative approach. A qualitative approach is used because researchers were planners, interpreters of data/information, and ultimately at the same time become reporters of research results. Thus, the researcher became the main actor in the entire process of this research.

Descriptive methods were selected so it will be more directive in conducting more significant writing and observation. As stated by Denzim and Lincoln (2005: 3) in [4], that qualitative research can be defined as a situated activity that locates the observer in the world. The starting point of this research is the aspect of social interaction. This aspect is used to prevent research from going out of the raised theme, as well as to facilitate the researcher in conducting research. Therefore, the main instrument in this study was the researcher himself. The instruments compiled were intended to capture broader information and to sharpen the results of observations. The working hypothesis built in this study refined the previous hypotheses and was expected to be useful for similar studies in the future.

This study focused on taking data through information submitted by informants. The information provided by the informant was obtained through a series of dialogues, both structured and not structured, in accordance with the research instruments that were made by the researcher.

Determination of informants was based on the initial information about the social application of the community [5]. A base informant was a person or group of people considered capable of providing general information about the social interaction of disability students with non-disabilities, disability students with disability students and students with disabilities with volunteers. This field study consisted of (1) observation by directly observing existing problems using the researcher's sense of sight. This is in line with reference [6] opinion that qualitative data are records of observation or interaction that are complex and context, and they are not easily reduced immediately to numbers. The observations used were nonparticipant observation. (2) The second instrument was indepth interviews. The interview in this study had the purpose of gathering oral information, by asking the informant directly to find out what was in the mind of the informant and being able to get information about what the researcher observed. (3) Documentation was used to look for data regarding matters or concepts in the form of book notes, magazines and others.

Data analysis used in this research was qualitative descriptive analysis. Data were collected first before being interpreted. This means that the data were processed in advance through systematic procedures or phases.

The selection of data analysis has answered the problems formulated from the beginning and has been developed after the researcher was in the field. Reference [7] further explains a number of ways of analyzing in three main groups: (1) memos, (2) categorizing strategies (such as coding and thematic analysis), and (3) connecting strategies (such as narrative analysis). By using this method of analysis, it was expected that the data obtained became more complete, more in-depth and credible and meaningful so that research objectives are achieved.

Data validation according to Nasution [8] is "... to determine the validity of the data, examination techniques are required." Triangulation is used in this study to validate the data. The purpose of triangulation is to check the truth of the data about social interaction in social interactions that occur with students with disabilities and the data obtained from other sources in various phases of research in the field, at different times, and often using different methods.

The intact form generated from this study is a description of the social interaction of students with disabilities at Lambung Mangkurat University which was limited by the social interactions of students with disabilities and non-disabled 
students, students with disabilities with students with disabilities, and students with disabilities with volunteers. Descriptive descriptions have the purpose to reveal a very complex social reality.

\section{RESUlt AND DisCUSSION}

Social processes are interaction ways that can be seen if individuals or social groups meet each other and determine the system and forms the relationship that causes the existing patterns of life change. The social process also describes the mutual influence between various aspects of common life, for example, influences between society and politics, politics with economics, economics, and law, and so on.

The general form of a social process is a social interaction which can also be called a social process. This is because a social interaction is the main condition for social activities. Social interaction describes some dynamic social relationships that involve relationships between individual people, between human groups, and between individuals and human groups. Social interaction between human groups occurs between groups as a whole and usually does not involve the members' matters.

The social interaction that occured between students with disabilities was considered positive. Fellow deaf students communicated using sign language that could be understood by each other. Negative interactions occurred due to differences in the use of signs by deaf students who had a residual hearing with deaf students without remaining hearing. This had caused one of the students to stop studying. The use of excessive expression could lead to misunderstandings among deaf students, as well as differences in the use of SIBI (Sistem Isyarat Bahasa Indonesia, Indonesian Sign System) and BISINDO (Bahasa Isyarat Indonesia, Indonesian sign language) that once made deaf students confused.

Students with disabilities who have different barriers generally interacted positively, there was no negative impression on each other. Disability students who understand one's barriers well tended to interact a lot and asked for help from volunteers; the social interaction between them can be inferred as a positive one. The volunteers who had free time outside lectures also tried to help students with disabilities according to their abilities. Registered volunteers generally have developed empathy so they tried to help students with disabilities if needed.

So far, there has been no dispute between students with disabilities and volunteers, except for students with disabilities who did not want to be accompanied or students with disabilities who did not want to follow academic advice from volunteers. Positive interaction occured because this interaction was shown by non-disabled students who tried to interact with students with disabilities by learning sign language and assisting students with disabilities when volunteers could not help. Disability students also welcomed them by teaching them how to communicate so that they could understand and made friends with non-disabled students.

The form of negative interaction was indicated by the presence of non-disabled students who did not want to learn signs or interact with students with disabilities. This interaction sometimes occured when group assignments and disability students were not actively involved. This negative form was more visible because non-disabled students who interacted with students with disabilities tended to be the same people, and sometimes non-disabled students spoke by themselves without involving students with disabilities when they were near, even though this was mostly caused by lack of understanding about the needs and importance of information access and equalization of information and needs.

There were a number of constraints in the interactions conducted by students with disabilities, namely (a) language constraints. Language barriers are a major factor that impedes the social interaction of students with disabilities with those around them, especially in the case of deaf students. (b) Nondisabled students who are still more selfish or reluctant to interact and have lack of empathy with students with disabilities, in the end, make interaction infrequent. (c) The habits of talking in a common way that non-disabled students who came from non-inclusion schools had sometimes made deaf students felt they were not invited to interact.

Supporting factors for social interaction are (a) a sense of empathy, understanding the obstacles experienced by disability students inspireing the desire to help around them both volunteers and non-disabled students, (b) and the desire to know and learn. Non-disabled students who have the desire to learn about different ways of learning and how to communicate with students with disabilities, generally build good interactions with students with disabilities.

Changes in learning outcomes with the interactions that occured in students with disabilities were (a) good social interaction among students with disabilities and volunteers and non-disabled students who helped them in the learning process tend ed to have better academic achievement than students with disabilities who refused to be helped, (b) students with disabilities who did not want to accept the opinions of volunteers or non-disabled students. It is often because they thought their opinions or understanding were the most correct that made them more often experience obstacles in academic, especially when doing assignments and examinations.

In social interaction, students with disabilities who understood their own condition and were honest, were more able to place themselves in interaction. If they could not understand some matters, the students would ask and it would be explained by the others until they understood so that there would be no misunderstanding. Disability students who always thought they could understand without asking tended to misunderstood the matters and the information in the interaction was not conveyed properly.

After some time, there were changes in the social interaction of students with disabilities. Disability students became more accustomed to interacting with non-disabled students and vice versa. Social interactions that went well made students with disabilities in general and deaf students especially became aware regarding the existence of many words that have not been translated to sign language yet. This encouraged students with disabilities to study harder, especially 
regarding the structure of Indonesian language and the understanding of many words that have not been translated.

In some cases of students with disabilities, unfortunately, some were not changed. This includes students with disabilities who refused volunteers' assistance. Actually, there were no special groups of students with disabilities. However, perhaps due to the similarity in the barriers they experience, students with disabilities tended to gather with their peers, especially deaf students, at the beginning of campus life. At present, students with disabilities gathered more often with nondisabled students and opening themselves to volunteers, as time goes by.

A social interaction will not be possible if it does not meet two conditions, namely the existence of social contact, and the existence of communication [9]. Based on the results of the research conducted, the interactions that occured between students with disabilities and non-disabilities have positive and negative social interactions. This positive interaction is in line with the existence of social contact and communication in accordance with the theory of [9]. Positive interactions are in form of doing teaching and learning each other because of a common goal agreement, such as non-disabled students learning sign language, learning braille, learning to recognize, and mutual tolerance of students with disabilities. Negative interactions also still occured between students with disabilities and non-disabilities, such as the difficulties of disability students starting to interact. This is because of difficulties in communicating and saying things that want to be conveyed due to language constraints, communication and previously in the community of fellow disabled people in SLB so they need to adapt to be able to establish interactions with inclusive communities.

Social interaction between students with disabilities tended to be positive and negative. Positive interactions occured because each could understand and helped one another. This is because each student with disabilities is aware of each other's conditions and needs. While negative interactions occur because students with disabilities who tended to be quiet and rarely explained the difficulties they faced.

Social interaction between students with disabilities and volunteers tended to be positive and negative too. Positive interactions occured because volunteers had good empathy and understood the conditions of students with disabilities and assisted the lectures by becoming a note taker besides in fact, they were from special education majors. Negative interactions occur because students with disabilities sometimes did not want to follow volunteers' advice because of the difficulties to understand it and to do it.

Reference [10] more deeply states that social interaction is the process of an individual being able to adjust automatically to another individual, where he is influenced by another. One individual can also adapt automatically to another individual, where the other individual is influenced by himself first. Therefore, social interaction will work well if there are a [12] mutual understanding of each other's needs, an adjustment to each other and an acceptance of each other's shortcomings and tolerance to each other.

According to [11], there are several factors that can influence social interaction, which are: (a) gender; male tendency to interact with peers/colleagues is greater than women, (b) extrovert personalities; extrovert people are more conformity than introvert. (c) the size of the group; the influence of the group becomes greater if the size of the group increases, (d) the desire to have status; the urge to have status is what causes a person to interact with colleagues. Individuals will find strength in defending themselves in the struggle for a place or status especially in a job. (e) Interaction of parents; unpleasant home atmosphere and pressure from parents encourage individuals to interact with their peers. (f) Education; high education is one of the factors in encouraging individuals to interact, because people with high education have broad knowledge, which supports their society. These things influence social interaction to be positive and negative.

\section{CONCLUSION}

There are two related patterns of social interaction in class learning sessions of students with disabilities in Higher Education. They are (1) positive social interaction, which is formed because of cooperation, understanding in communication, and acceptance of each individual to understand and learn from each other. (2) Social interaction is negative due to several factors such as communication barriers, introverted personality of students with disabilities, and fear of starting communication, understanding, and family support. Meanwhile, non-disabled students need empathy, mutual understanding and the ability to establish communication so that interaction patterns can be run well.

\section{REFERENCES}

[1] W. Bimo, Pengantar Psikologi Umum. Yogyakarta: ANDI, 2003

[2] S. Santoso, Teori-Teori Psikologi Sosial. Bandung: Refika Aditama, 2010 .

[3] S. Soekanto, Soerjono, and B. Sulistyowati, Sosiologi Suatu Pengantar. Jakarta: Rajawali Pres, 2012

[4] J. W. Creswell, Penelitian Kualitatif dan Desain Penelitian Riset. Yogyakarta: Pustaka Pelajar, 2013.

[5] H. Hamidi, Metode Penelitian Kualitatif. Malang: UMM Pres, 2004.

[6] R. L. Daft, Manajemen. 6th ed. Jakarta: Salemba Empat, 2006.

[7] J. A. Maxwell (Ed.), Qualitative research design: An interactive approach (2nd ed.). Thousand Oaks, CA: Sage, 2005.

[8] Nasution, Metodologi Penelitian Kualitatif Naturalistik. Jakarta: Sinar Grafika, 1996

[9] S. Soekanto, Sosiologi Suatu Pengantar. Jakarta: Raja Grafindo Persada, 2005.

[10] W. A. Gerungan, Psikologi Sosial. Bandung: PT. Tarsito, 2006

[11] F. J. Monks, Psikologi Perkembangan (Pengantar Dalam Berbagai Bagiannya). Yogyakarta: Gadjah Mada University Press, 2002. 